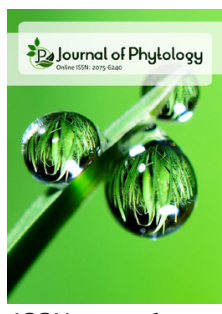

ISSN: $2075-6240$

Received: September 05, 2020

Revised: March 30, 2021

Accepted: April 05, 2021

Published: April 17, 2021

${ }^{*}$ Corresponding author:

B. P. Bhusare,

Email: bhushanbhusare1990@

gmail.com

\section{Uraria picta: A comprehensive review on evidences of utilization and strategies of conservation}

\author{
B. P. Bhusare ${ }^{\text {* }}$, M. L. Ahire ${ }^{2}$, C. K. John³, T. D. Nikam \\ 'Department of Life Science (School of Science), Sandip University Nashik-422213, Maharashtra, India, ${ }^{2}$ Department \\ of Botany, Yashavantrao Chavan Institute of Science, Satara -415001, Maharashtra, India, ${ }^{3}$ Plant Tissue Culture \\ Division, CSIR-National Chemical Laboratory, Pune-411008, Maharashtra, India, ${ }^{4}$ Department of Botany, Savitribai \\ Phule Pune University, Pune, 411007, Maharashtra, India
}

\begin{abstract}
Uraria picta (Jacq.) DC. (Prishnaparni) is one of the most important medicinal plants used in different traditional systems of medicines including the Ayurveda and Traditional Chinese medicine. The major use of this plant was found in the most popular Ayurvedic formulation "Dashmula" and in several many other important Ayurvedic formulations. IUCN placed this woody herb in the least concern category as per version 3.1. It has extensive therapeutic uses and pharmacological activities. Though this plant is a source of many phytochemicals, the uses are uncertain because the raw plant parts or crude extracts are being used in all formulations. Therefore, extensive investigations are necessary to focus on the identification of these phytochemicals. It is an urgent need to give special attention to collecting various aspects and more efforts are required in all areas for utilization and conservation of this valuable medicinal herb. Herein, a compilation of all information with various aspects has been presented, including the authors published work on Uraria picta. This review pursues attention towards biological activity, phytochemical profile, utilization, propagation and conservation of Uraria picta.
\end{abstract}

KEYWORDS: Biological activity, Dashmula, In vitro propagation, Phytochemical

\section{INTRODUCTION}

In addition to the allopathic system of medicine, Ayurveda, Homeopathy, Unani, Siddha and Yoga are also used as traditional systems of medicines in India. Among these, Ayurveda is the oldest system of medicines which originated in pre-vedic period. Rigveda and Atharvaveda are the most primitive documented evidences on ancient Indian knowledge about medicines. Ayurveda is an upvedas of Rigveda and Atharvaveda. Of the different Ayurvedic texts, Charak Samhita and Sushruta Samhita deal elaborately with maintenance of health throughout the life and its various phases and developed a wide range of therapeutic measures related to physical, mental, social and spiritual health. Ayurveda, mostly deals with the herbal based medicines which contains therapeutic potentials description of over 2000 plants. As the Ayurvedic medicines are of natural origin, found to be many beneficial effects over allopathic system, as observed satisfactory effects of these medicines to temperament of individuals and fewer side effects. The overall cost of treatment is also low as compare with the allopathic systems. In India, more than 7500 plant species are being used in various alternative medicinal systems (Mukherjee $\&$ Wahile, 2006). Recently, the interest in the use of herbal preparations has grown dramatically throughout the world (Patwardhan et al., 2003)

Most of recent pharmaceutical drug have been discovered from the traditional knowledge and methods used by tribal peoples (Balick \& Cox, 1996; Gilani \& Rahman, 2005). Many of the modern day drugs are derived from plant based products. Furthermore, it is estimated that about $25 \%$ of modern drugs and as many as $60 \%$ of antitumor drugs are derived from natural products (Brower, 2008; Newman \& Cragg, 2012). According to the World Health Organization (WHO), as many as $80 \%$ of the world's population depends on traditional medicine and about $65 \%$ of the population in the rural areas use Ayurvedic and medicinal plants to meet their primary health-care needs in India (WHO, 2002).

Among the Ayurvedic medicines, Dashmula plants are top traded group. It is estimated that more than 10,000 Metric tonnes of Dashmula plant raw drugs are being consumed every year by Indian herbal industry contributing to nearly

Copyright: ( ) The authors. This article is open access and licensed under the terms of the Creative Commons Attribution License (http://creativecommons.org/licenses/by/4.0/) which permits unrestricted, use, distribution and reproduction in any medium, or format for any purpose, even commercially provided the work is properly cited. Attribution - You must give appropriate credit, provide a link to the license, and indicate if changes were made. 
Rs. 500 crores turnover (Ved \& Goraya, 2008). Dashmula is the compound which is prepared by using powder of roots of ten different medicinal plants such as Aegle marmelos Corr., Desmodium gangeticum DC., Gmelina arborea Roxb., Oroxylum indicum Vent., Premna integrifolia Linn., Solanum indicum Linn., Solanum xanthocarpum Schrad., Stereospermum suaveolens DC., Tribulus terrestris Linn., Uraria picta (Jacq.) DC (Singh et al., 2011). Among these, one of the major ingredients is the roots of U. picta. Apart from Dashmula, the plants is also used in several other Ayurvedic formulations such as: Abhrak bhasma, Agastya hartiki rasayana, Amritaprasa ghrita, Amritarishta, Angamardaprasaman kashay churna, Anu taila, Bharngi guda, Brahma rasayan, Brhacchagaladya ghrita, Brihatmasa taila, Dahika ghrita, Dantyadyarishta, Darunagaradi kvath churna, Dahmula taila, Dashmoola ghrita, Dashmool katutray kvath churna, Dashmool kvath churna, Dashmoolpanchakoladi kvath churna, Dashmoolsatpalaka ghrita, Dashmularishta, Dhanvantara ghrita, Dhanvantara taila, Indukanta ghrita, Kalyanak ghrita, Madhyam narayan taila, Mahakalyanak ghrita, Maha narayana taila, Maha panchgavya ghrita, Maha vishgarbha taila, Mritasanjivani sura, Mushikadya taila, Narayana taila, Rajanyadi churna, Rasnadi kvath churna, Sahacharadi taila, Shira shuladi vajra rasa, Siva gutika, Sukumar ghrita, Vastyamayantaka ghrita, Vayucchaya surendra taila, Vidaryadi ghrita, Vidaryadi kvath churna, Vishnu taila, Vyaghri taila (Ahire \& Nikam, 2013).

In Ayurveda 'Chyawanprash' is the traditional multi herbal formulation, which is widely used as health tonic, rejuvenator, anabolic, immune-modulator and memory enhancer. Chyawanprash are of different class like Dashmula, Ashtavarga and Chaturjata. Among these, Dashmula is a best Ayurvedic formula used for treating fatigue, worries, poor sleep. It is also used as hormone to cures post-delivery problems, all types of inflammations and detoxify the entire body. Dashmula is an excellent sedative used in balancing the tri doshas VATA, PITTA and KAPHA (Kasar et al., 2007).

Genus Uraria belongs to family Fabaceae, contains about 35 species distributed throughout the world including Uraria picta (Hutchinson \& Dalziel, 1958). Uraria picta also recognised by Doodia picta Roxb., Hedysarum pictum Jacq., Uraria aphrodisiaca Welw., Uraria leucantha Span., Uraria linearis Hassk. It is commonly called as Dabra, Pithvan, Prishnaparni. In Nigeria, U. picta is locally known as 'Alupayida' (Yoruba) meaning 'the power of changing object'; 'kaskaifi', 'dakushe', 'wutsiyarbera', 'wutsiyarkusu' (Hausa) meaning 'weapon sharp edge-destroyer'; and “Obuŏ; do dumbwada' (Igbo) meaning 'tail bearer that seeks help to dig the ground'. Chinese traditionalists called U. picta Mei Hua Li Wei Dou (Oyesiku et al., 2013). In spite of the large number of medicinal uses, the genus Uraria is neglected and got a very little attention from researchers in view of taxonomical, pharmacological and phytochemical studies. Few reports were available in the literature about ethnobotanical role of this genus (Waghire et al., 2013).

\section{CLASSIFICATION AND DISTRIBUTION OF \\ URARIA PICTA}

\section{Classification of Plant}

Kingdom: Plantae

Clade: Fabids (Eurosids I)

Order: Fabales

Family: Fabaceae

Subfamily: Faboidae

Tribe: Desmodieae

Subtribe: Desmodiinae

Genus: Uraria

Species: U. picta

\section{Distribution}

U. picta is commonly found in areas of dry grass-lands, grassland with scattered trees including Acacia; waste places, on rocky ground, deep sandy soils; by riverbanks, flood-plains and gallery forest. U. picta is a widespread species found in tropical Africa, South and South East Asia and Australia. It is not considered to be specifically threatened or in decline at present. The species does not meet any threatened criteria therefore a rating of Least Concern is given (Groom, 2012).

\section{BOTANICAL DESCRIPTION}

Uraria picta is annual herb, stem woody at maturity, and it covered with scarce modified fine, short, straight and hooked hairs. Plant body is erect, height ranging from 0.5 to $2.0 \mathrm{~m}$. Leaves are dimorphic, young leaves are simple and at maturity they are odd-pinnately compound covered with the hairs as present of stem (Figure 1). Inflorescence is of raceme type. Racemes are terminal and elongated upto 1.5 feet. The flowers are small, present in large number (35-75) on dense spike (figure 1). The inflorescence axis is pink, purple or pale lead in colour. Flowers are purple, pink or bluish in colour. Flowers are bracteate, bracts persistent at the base and apex. Calyx is four mm long; teeth plumose much longer than the short tube. Corolla papilionaceous, sepals are 4-5 mm long.Pods are segmented with 3-6 segments, each 2-3 mm broad and 5-9 mm long, smooth, polished, folded on one another (Hutchinson \& Dalziel, 1958; Bhattacharya \& Datta, 2010). Pods contain 2-6 seed and segments are nearly separated (Waghire et al., 2011). Flowering and fruiting time in the month of august to September.

\section{PHYTOCHEMICAL CONSTITUENTS}

U. picta constitute number of important bioactive compounds such as phenolics, tannins, saponins, cardiac glycosides, flavonoids, isoflavanones, triterpens and steroids (Table 1). Two Isoflavanones namley 5,7-dihydroxy-20-methoxy-30,40methylenedioxyisoflavanone and 40,5-dihydroxy-20,30dimethoxy-7-(5-hydroxyoxychromen-7yl)-isoflavanone were isolated from roots (Rahman et al., 2007). Additionally, 
researcher also identified stigmasta-4,22-diene-3-one, b-sitosterol and lupeol by direct comparison of the spectral data to those published in the literature (Kojima et al., 1990; Parsons, 1991; Rahman et al., 2007). Yadav and his

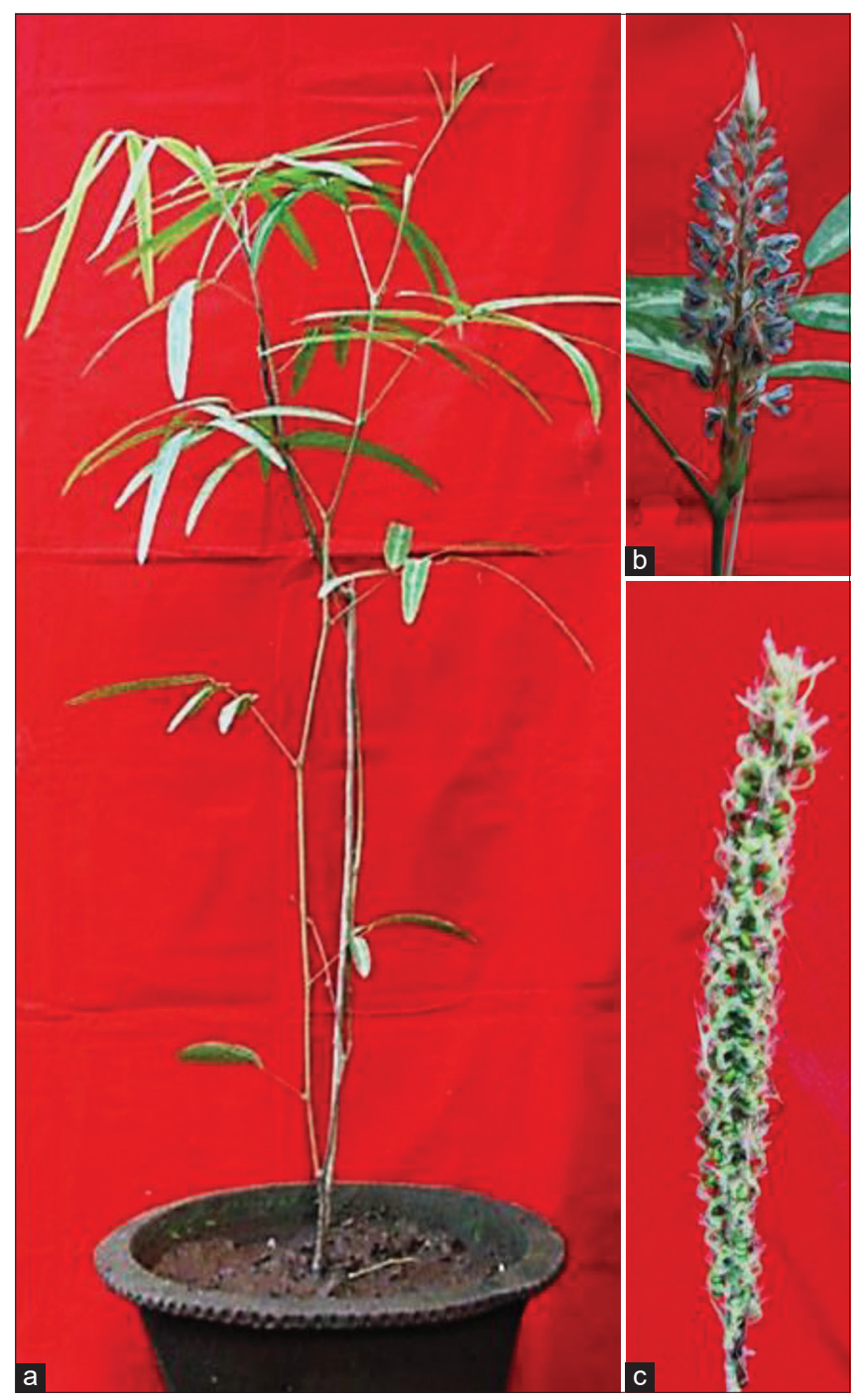

Figure 1: Habit of Uraria picta (Jacq.) DC. a: Well grown mature plant; b: Inflorescence and c: Matured inflorescence of $U$. picta with green pods team reported the isolation, quantitation and validation of flavone glycoside Rhoifolin from aerial parts of $U$. picta (Yadav et al., 2009). Turner \& Harborne, 1967 and Ambe et al., 2010, reported the Canavanine, essential and non-essential amino acids from the seed of it. The albumin like proteins and different fatty acids such as linoleic acid (38.9\%), palmitic acid (14.2\%), linolenic acid (11.3\%) and oleic acid (11.1\%) from seeds (Ambe et al., 2010; Waghire et al., 2011). Along with different phytochemical, determined different macro elements such as $\mathrm{Na}, \mathrm{K}, \mathrm{Ca}, \mathrm{Mg}$ and $\mathrm{P}$ in leaves of the plant (Saxena et al., 2014).

\section{ETHNOMEDICINAL USES}

Ethnomedicines defined as the use of plants by humans as medicines (Farnsworth, 1994). Ethnopharmacology is a highly diversified approach to drug discovery involving the observation, description and experimental investigation of indigenous drugs and their biologic activities. Attention of people received towards the traditional ethno-botany due to their wide local acceptability in recent years (Tripathi, 2000). Tribal peoples of Purulia district in West Bengal used root paste of U. picta, Mahadevjata and Ishwarjata, with honey (4:2) once daily for 5 days as abortificients. Leaf paste is given twice daily as antidote to snakebite (Chakraborty \& Bhattacharjee, 2006). Tribal's of the Saurashtra region used seed paste for haemorrhoids disease (Jadeja et al., 2006). Tribal of Chittagong hill used the leaf paste for suppuration of boil disease and applied on it for burst (Yusuf et al., 1994, 2007). The combination of leaves and roots of Aristolochia indica, Desmodium motorium and U. picta are crushed and the juice taken orally. Tribal communities of Chitrakoot (MP) and Wayanadu districts of Kerala applied leaf paste on cuts and wounds twice a day (Sikarvar et al., 2008; Thomas et al., 2014). U. picta alone or on combination with others are used as an antidote or for gall bladder pains in Kushita and Sherpur district in Bangladesh (Rahmatullah et al., 2009; Alom et al., 2011). Jain \& Singh in 2010, reported that, half teaspoon of root decoction is taken orally for seven days in snakebite and sore mouth (Jain \& Singh, 2010). The paste made from three gram flowers of $U$. picta is taken once a day in empty stomach to sterile women for one month for pregnancy (Sahu et al., 2010). The different communities like Gond, Kols, Mushar, Baiga

Table 1: Phytochemicals constituents from different plant parts of Uraria picta

\begin{tabular}{|c|c|c|c|}
\hline Phytochemical constituents & Plant parts used & Solvent used for extraction & Reference \\
\hline Alkaloid & leaves, roots and stem & ethanol and methanol & Saxena et al., (2014) \\
\hline Amino acids & Leaves & ethanol and water & Garg et al., (2012) \\
\hline Carbohydrate & Leaves & ethanol and water & Garg et al., (2012) \\
\hline Cardiac glycosides & leaves, roots and stem & $\begin{array}{l}\text { diethyl ether, chloroform, ethanol, ethyl acetate, } \\
\text { methanol, petroleum ether and water }\end{array}$ & Saxena et al., (2014) \\
\hline Flavonoides & leaves, roots and stem & chloroform, ethanol, methanol and water & Garg et al.,(2012) and Saxena et al.,(2014) \\
\hline Phenols & leaves, roots and stem & aqueous and methanol & Saxena et al.,(2014) \\
\hline Saponin & leaves, roots and stem & ethanol, methanol and aqueous & Saxena et al., (2014) \\
\hline Steroids & leaves, roots and stem & $\begin{array}{l}\text { aqueous, diethyl ether, chloroform, ethanol, ethyl } \\
\text { acetate, methanol, petroleum ether and water }\end{array}$ & Garg et al., (2012) and Saxena et al., (2014) \\
\hline Tannins & leaves & diethyl ether, ethanol, ethyl acetate and water & Garg et al., (2012) and Saxena et al., (2014) \\
\hline Triterpenoides & leaves & $\begin{array}{l}\text { aqueous, diethyl ether, chloroform, ethanol, ethyl } \\
\text { acetate, methanol, petroleum ether and water }\end{array}$ & Garg et al., (2012) and Saxena et al., (2014) \\
\hline
\end{tabular}


and Nutts from Vindhya region of Uttar Pradesh used U. picta against bodyache and wounds (Chaudhary, 2010). Whole plant is used by the tribal's of Tamil Nadu for the antibacterial purpose (Jayaprasad et al., 2012). Root decoction is used against snake bite in Chhattisgarh region (Minu et al., 2012). The root for snake bite, vomiting, fever, cough and gonorrhea in Nasik district (Ahire, 2012). The tribal of Jhabua district of Madhya Pradesh used root decoction for respiratory diseases (Wagh \& Jain, 2014, 2015). A decoction of whole plant is used for the treatment of female infertility by the Badagry people of Lagos State, Nigeria (Makinde et al., 2015).

\section{THERAPEUTIC USES}

U. picta has been historically used as purported medicines and magic's. The whole plant and different plant parts are being used in different therapeutic treats (Prasad et al., 1965; Osazuwa \& Igboechi, 1988; Igboechi et al., 1989). The leaf powder is used to cure the gonorrhea and for uterus contraction which leads to abortion (Ainslie, 1937). Aphrodisiac ingredient detected in alcoholic and aqueous extracts in roots (Dalziel, 1937). The leaves are used as antiseptic. These are also used in treating child malaria as it showed traces of alkaloids (Adegoke et al., 1968). The leaves prove to reactivate the movement of foetus in pregnant women and have the power to change the sex of a foetus (Lambo, 1979). It is also reported that the fresh leaves juice was proved to be skin hardener against sword or knife cut when rubbed on skin (Lambo, 1979). It is used in the preparation of Ayurvedic drug Abana, which is useful in the treatment of hypertension, tachycardia and angina (Khanna et al., 1991). Pods are useful in sore-mouth of children. Roots and leaves are used for treatments of typhoid and tetanus. Traditionally, the plant is used as an antidote to the venom of Echis carinata (Kirtikar \& Basu, 1993; Hamid et al., 2004). The use of dashmula, for significant improvement in neurological disorder (Garg et al., 2012). Decoction of root and whole plant is given on heart trouble, fractured bones, cough, chills, fevers, gonorrhea, gout, swelling, obesity and on skin diseases (Mishra et al., 2012; Rahman \& Parvin, 2014). Protective effect of aqueous extract of Uraria Picta on acetaminophen induced nephrotoxicity in rats (Kale et al., 2012; Odubanjo et al., 2013). Odubanjo et al., 2013 reported that use of phytochemicals for treatment of Alzheimer's disease (Odubanjo et al., 2013).

\section{PHARMACOLOGICAL ACTIVITIES}

\section{Antimicrobial Activity}

Different plant part extract and isolated bioactive compounds showed antimicrobial activity. Chemical isolate from the leaf extract of $U$. picta showed antimicrobial activity (Osazuwa \& Igboechi, 1988). Two isoflavanones isolated from root bark showing the antimicrobial activities against both Gram +ve and Gram -ve bacteria and fungi (Ved \& Goraya, 2008). The methanol extract showed significantly higher inhibitory effects on the growth of Escherichia coli, Salmonella typhi, Staphylococcus aureus and Streptococcus pneumoniae (Khalili et al., 2013). Additionally, the antibacterial activity of methanolic extracts of leaf, root and callus against the pathogenic bacteria (Ahire et al., 2011).

\section{Acaricidal Activity}

Potent acaricidal properties of methanolic extracts of $U$. picta by using human and domestic animal model compared to the aqueous extract (Ahirrao et al., 2007).

\section{Hypolipidaemic Activity}

Abana tablets is prepared from mixture of different herbals including Uraria showed hypolipidaemic activity in rats (Khanna et al., 1991).

\section{Anti-inflammatory Activity}

The anti-inflammatory of aqueous and methanolic extracts of $U$. picta using in vitro and in vivo animal models. The evaluation parameter of in vitro model was nitrous oxide radical scavenging assay, lipooxygenase assay and Carrageenan induced rat paw edema model was used in vitro model (Ahirrao et al., 2007).

\section{Anti-oxidant Activity}

The total antioxidant capacity of ethanolic extract. U. picta extract showed significant antioxidant activity. The antioxidant activity was found to be associated with presence of phenolic, flavonoid, sterol and terpene derivatives (Patel et al., 2011). It also inhibits the acetylcholineesterase and butyrylcholinesterase which could make it a good resource to treat Alzheimer's disease (Odubanjo et al., 2013). Poly herbal formulation consisting with U. picta helps to protect the liver cells from $\mathrm{CCl}_{4}$ induced liver damages (Ghosh et al., 2015).

\section{IN VITRO CULTURE}

Natural regeneration of Prishnaparni is less due to poor seed viability and low percentage of germination. Studies were conducted to enhance the percentage of germination of the viable seeds (Okusanya et al., 1991; Ahire et al., 2009). Although plants can be raised by sowing seeds directly in the field, it results in very poor crop stand and yield. In vitro clonal propagation technique is applied to produce large numbers of identical individuals and conservation. In plant species like Prishnaparni, the whole plants are uprooted for the medicinal preparations as the roots contains the active metabolites. This generated extra pressure on natural populations of the plant. In earlier reports, the plant is considered to be rare and endangered in some parts of India (Anand et al., 1998; Gurav et al., 2008; Ahire et al., 2009; Rai et al., 2010). Recently, the plant is categorized in least concern category by IUCN (Groom, 2012). In this context, several authors has made efforts for in vitro clonal propagation of this plant using different plant parts as explants (Table 2). Micropropagation of Prishnaparni using cotyledonary node and node as explants has been reported through direct organogenesis (Anand et al., 1998; Mukundan et al., 2002; Gurav et al., 2008; Rai et al., 
2010; Parmar \& Jasrai, 2012; Parmar \& Jasrai, 2015). In addition to this, callus mediated shoot organogenesis using leaf explants as well as hardening and acclimatisation of these plantlets (Figure 2). Among the different reports on shoot organogenesis, higher number of shoots per culture was reported (Ahire et al., 2011).

Efficient root initiation and survival of the hardened plantlets under field condition is the key success of any micropropagation protocol (Nikam et al., 2013). Among the different micropropagation reports available on U. picta, most of the authors succeeded to produce roots either on half strength MS basal medium or the medium fortified with IBA. Maximum number of roots/shoot (16.2 \pm 2.4 ) was found on half strength MS basal medium $+0.25 \mathrm{mg} / \mathrm{l}$
IAA $+0.50 \mathrm{mg} / \mathrm{l}$ IBA (Rai et al., 2010). The acclimatized in vitro grown plantlets showed $98 \%$ survival (Ahire et al., 2011). The genetic fidelity analysis using randomly amplified polymorphic DNA (RAPD) analysis of regenerants revealed $100 \%$ uniformity as mother plants (Figure 3). Quantitative estimation of isoflavones from the roots of in vitro raised plantlets further confirmed the genetic identity of regenerants (Rai et al., 2010). In addition to the genetic fidelity, the antibacterial activity of methanolic extracts of in vitro raised callus in comparison with leaves and root harvested from wild plants (Ahire et al., 2011). Among the different extracts, callus extract showed strong antibacterial activity against pathogenic bacteria. The results suggested that, presence of higher concentrations of active chemical components (isoflavanoids) in callus cultures of $U$. picta.

Table 2: Shoot organogenesis in Uraria picta

\begin{tabular}{|c|c|c|c|c|}
\hline Explant & Medium and PGR used & Development Stage & $\begin{array}{l}\text { Number of shoots } \\
\text { per explant/culture }\end{array}$ & References \\
\hline \multirow[t]{2}{*}{ Axillary bud and node } & $\mathrm{MS}+2.47 \mu \mathrm{m} \mathrm{AS}$ & $\begin{array}{l}\text { Direct organogenesis (Bud } \\
\text { formation) }\end{array}$ & $7.1 \pm 0.6$ & Anand et al., (1998) \\
\hline & $\begin{array}{l}\mathrm{MS}+5.37 \mu \mathrm{m} \mathrm{NAA}+2.22 \mu \mathrm{m} \\
\mathrm{BAP}\end{array}$ & $\begin{array}{l}\text { Indirect organogenesis (Callus } \\
\text { inoculated on } 0.13 \mu \mathrm{m} \text { BAP) }\end{array}$ & $17.3 \pm 2.8$ & \\
\hline Node & $\mathrm{MS}+1 \mathrm{mg} / \mathrm{l} \mathrm{BAP}$ & Direct organogenesis & - & Mukundan et al., (2002) \\
\hline Cotyledonary node & $\mathrm{MS}+13.2 \mu \mathrm{M}$ BAP & Direct organogenesis & $36.3 \pm 1.7$ & Gurav et al., (2008) \\
\hline Nodal stem segment & $\begin{array}{l}\mathrm{MS}+0.1 \mathrm{mg} / \mathrm{l} \mathrm{IAA}+0.1 \mathrm{mg} / \mathrm{l} \\
\mathrm{BAP}+25 \mathrm{mg} / \mathrm{l} \mathrm{AS}+0.5 \mathrm{mg} / \mathrm{l} \mathrm{GA}\end{array}$ & Direct organogenesis & $19.6 \pm 2.6$ & Rai et al., (2010) \\
\hline Leaf & $\mathrm{MS}+4.44 \mu \mathrm{M}$ BAP & Indirect organogenesis & $58.8 \pm 0.8$ & Ahire et al., (2011) \\
\hline Node & $\mathrm{MS}+4.44 \mu \mathrm{M}$ BAP & Direct organogenesis & $14.4 \pm 3.8$ & Parmar et al., (2012) \\
\hline Node & $\mathrm{MS}+0.5 \mathrm{mg} / \mathrm{l} \mathrm{TDZ}$ & Direct organogenesis & 10.3 & Parmar et al., (2015) \\
\hline
\end{tabular}
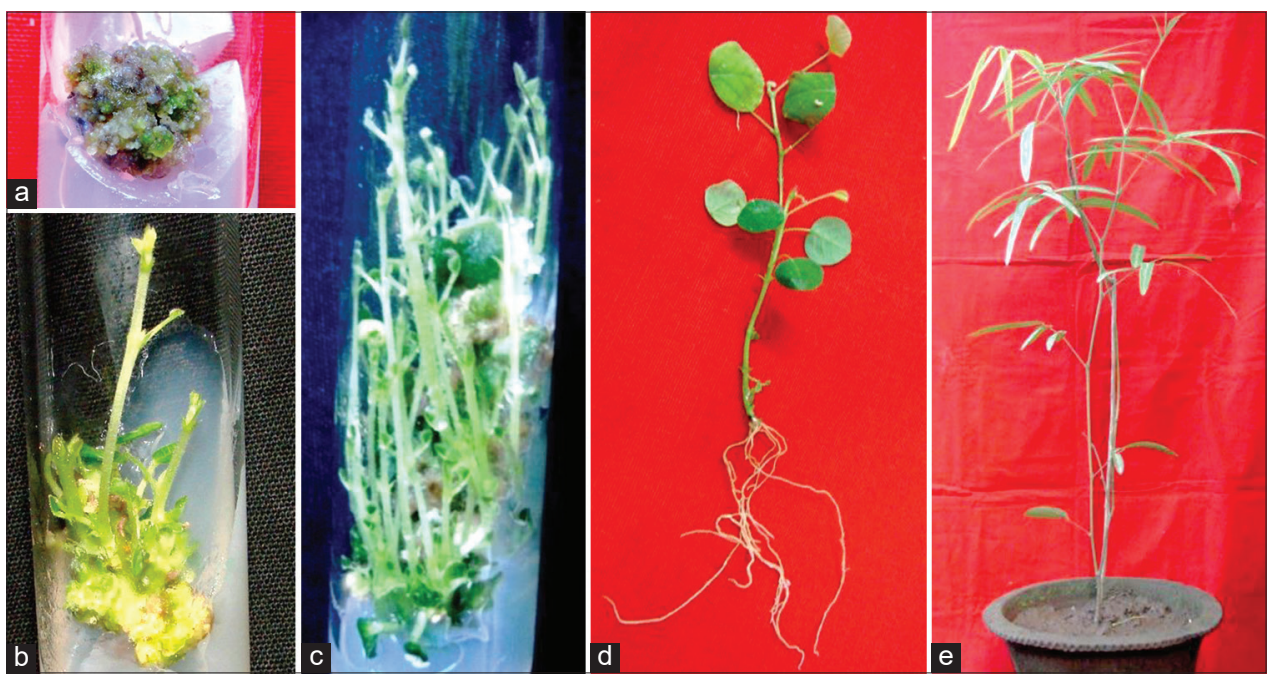

Figure 2: Indirect shoot regeneration of Uraria picta. (a) Leaf derived organogenic callus (b) Induction of shoot primordia from callus (c) elongated shoots (d) rooted shoot and (e) mature plant in natural conditions.

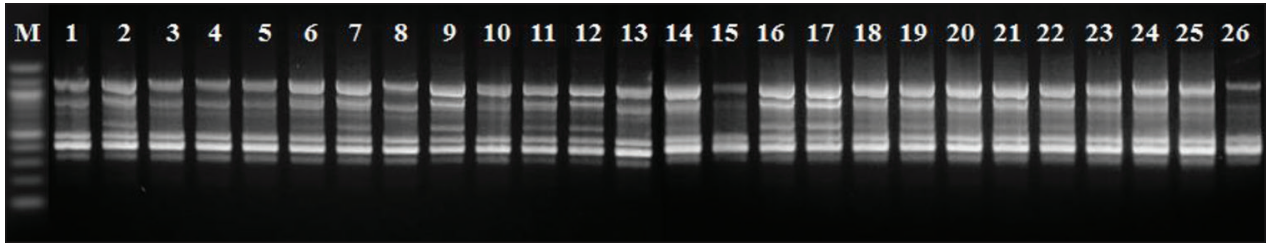

Figure 3: Genetic fidelity analysis of micropropagated plants using randomly amplified polymorphic DNA (RAPD), M 100-bp DNA ladder, lane 1 Mother plant, 2-26 micropropagated plants 


\section{CONCLUSIONS AND FUTURE PERCEPTIVE}

Dashmula is one such preparation where roots of ten different plant species are used in mixture, among these $U$. picta is one. Low rate of seed germination, long maturation period are major reason to restrict the population of it. Multiple uses of $U$. picta have resulted in destructive over-exploitation from the wild to satisfy the ever-increasing demand of pharmaceutical industries. Due to this reasons the available drug of Dashmula in the market is devoid of $U$. picta roots and hence the necessity of conserving it is almost needful. Though there were some attempts on in vitro shoot culture of $U$. picta but development of further methods are necessary for large scale propagation of this. Focus on root culture, somatic embryogenesis, elicitation, mutagenesis and transformation research may help in large scale propagation, improvement and their applications in many diseases. In vitro culture techniques can be an alternative to overcome the shortage of natural source of plant material and conservation of this plant. From phytochemical techniques the chemical profile, biological activity and characterization may be helpful in development of specific drug of Uraria picta.

\section{DECLARATION OF COMPETING INTEREST}

The authors report no conflicts of interest. The authors alone are responsible for the content and writing of this article.

\section{ACKNOWLEDGEMENTS}

The authors greatly acknowledge to the staff members of Department of Botany, Savitribai Phule Pune University and Department of Life Science (School of Science), Sandip University Nashik for providing constant support and facility.

\section{ABBREVIATIONS}

$\mathrm{BAP}=6$-Benzylaminopurine, GA3=Gibberellic acid, $\mathrm{IAA}=$ Indole-3-acetic acid,IBA=indole-3-butyric acid, $\mathrm{m}=$ meter, $\mathrm{mg} / \mathrm{l}=$ milligram per litre, $\mathrm{mm}=$ millimetre, $\mathrm{MS}=$ murashige and Skoog, NAA $=\alpha$-naphthaleneacetic acid, PGRs $=$ Plant Growth Regulators, RAPD $=$ Random Amplified Polymorphic DNA, TDZ=1-phenyl-3-(1, 2, 3-thiadiazol-5-yl)urea, $\mu \mathrm{M}=$ micro-molar

\section{REFERENCES}

Adegoke, E. A., Akinsanya, A., \& Naqvi, S. H. Z. (1968). Studies of Nigerian medicinal plants. I. A preliminary survey of plant alkaloids. Journal of West African Science Association, 13, 13-33.

Ahire, D. U. (2012). Survey of medicinal plants of Peth Taluka of Nasik Dist. (M.S.). Indian Jounral of Applied and Pure Biology, 27, 219-221.

Ahire, M. L., Ghane, S. G., \& Nikam, T. D. (2009). Seed viability and influence of presowing treatments on germination and seedling development of Uraria picta (Jacq.) DC. Seed Science and Biotechnology, 3, 48-53.

Ahire, M. L., Ghane, S. G., Lokhande, V. H., Suprasanna, P., \& Nikam, T. D. (2011). Micropropagation of Uraria picta through adventitious bud regeneration and antimicrobial activity of callus. In vitro Cel/ular and Developmental Biology - Plant, 47, 488-495. https://doi.org/10.1007/ s11627-011-9362-7

Ahire, M. L., \& Nikam, T. D. (2013). Biotechnological strategies for conservation of Uraria picta. Lap Lambert Academic Publishing,
Germany.

Ahirrao, P., Jagtap, A., Shirke, S., \& Fernandes, B. (2007) Comparative assessment of anti-inflammatory potential of Asparagus racemosus and Uraria picta. Proceedings of Life Sciences. Poster Communications: PC108.

Ainslie, J. A. (1937). List of plants used in native medicine in Nigeria. Imperial Forestry Institute.

Alom, N., Zohora, F. Z., \& Sultan, M. (2011) Ethnobotanical study of the Garo tribe of Sherpur district, Bangladesh. Journal of Taxonomy and Biodiversity Research, 5, 43-46.

Ambe, G. A., Lognay, G., Wathelet, B., \& Malaisse, F. (2010) Ethnobotanical and chemical surveys of an edible wild legume: Uraria Picta (Jacq.) DC. Ecology of Food and Nutrition, 40, 545-565. https://doi.org/10.1 080/03670244.2001.9991666

Anand, A., Rao, C. S., Latha, R., Josekutty, P. C., \& Balakrishna, P. (1998). Micropropagation of Uraria picta, a medicinal plant, through axillary bud culture and callus regeneration. In vitro Cellular and Development Biology, 32, 136-140. https://doi.org/10.1007/BF02822778

Balick, J. M., \& Cox, P. A. (1996). Plants, people and culture: the Science of Ethnobotany. Scientific American Library, New York.

Bhattacharya, A. \& Datta, A. K. (2010) Uraria picta: An overview. Medicinal and Aromatic Plant Science and Biotechnology, 4, 1-4.

Brower, V. (2008). Back to nature: extinction of medicinal plants threatens drug discovery. Journal of the National Cancer Institute, 100(12), 838-839. https://doi.org/10.1093/jnci/djn199

Chakraborty, M. K., \& Bhattacharjee, A. (2006). Some common ethnomedicinal uses for various disease in Purulia district, West Bengal. Indian Journal of Traditional Knowledge, 5(4), 554-558.

Chaudhary, R. S. (2010). Taxa of family Fabaceae: a potential of local medicinal values in Vindhya region Uttar Pradesh, India. International Journal of Pharma and Bio Sciences, 1, 46-53.

Dalziel, J. M. (1937). The useful plants of West Africa $1^{\text {st }}$ edition. Crown Agents for the Colonies, London.

Farnsworth, N. R. (1994). Ethnopharmacology and drug development. Ciba Found Symposium. 185, 42-51

Garg, N., Garg, M., Maan, A. S., Sandhu, B. S., Mittal, S., \& Goyal, S. (2012) Phytochemical studies and anti anxiey activity of Uraria picta leaves. Journal of Pharmaceutical Research and Opinion, 2, 39-40.

Ghosh, A., Kundu, A., Seth, A., Singh, A. K., \& Maurya, S. K. (2015). Preliminary evaluation of hepatoprotective potential of the polyherbal formulation. Journal of Intercultural Ethnopharmacology, 4, 118-124.

Gilani, A. H., \& Rahman, A. (2005) Trends in ethnopharmacology. Journal of Ethnopharmacology, 100, 43-49. https://doi.org/10.1016/j. jep.2005.06.001

Groom, A. (2012) Uraria picta. The IUCN Red List of Threatened Species: e.T19891465A20159472.

Gurav, A. M., Dhanorkar, V. M., Dhar, B. P., \& Lavekar, G. S. (2008). In vitro propagation of the medicinal plant Uraria picta (Jacq.) Desv.ex DC. From cotyledonary node and nodal explants. Pharmacognosy Magazine, 4, 239-245.

Hamid, H., Abdullah, S. T., Ali, A., Alam, M. S, \& Ansari, S. H. (2004). Anti-inflammatory and analgesic activity of Uraria lagopoides. Pharmaceutical Biology, 2, 114-116.

Hutchinson, J., \& Dalziel, J. N. (1958). Flora of West Tropical Africa. Grown Agents for Overseas Government and Administration, London.

Igboechi, A. C., Osazuwa, E. O., \& Igwe, U. E. (1989). Laboratory evaluation of the acaricidal properties of extracts from Uraria picta (Leguminosae). Journal of Ethnopharmacology, 26, 293-298. https:// doi.org/10.1016/0378-8741(89)90102-5

Jadeja, B. A., Odedra, N. K., \& Odedra, K. R. (2006) Herbal remedies used for haemorrhoids by tribals of Saurashtra, Gujarat. Indian Journal of Traditional Knowledge, 5, 348-352.

Jain, S. P., \& Singh, J. (2010) Traditional medicinal practices among the tribal people of Raigarh (Chattisgarh) India. Indian Journal of Natural Product and Resources, 1, 109-115.

Jayaprasad, B., Thamayandhi, D., \& Sharavanan, P. S. (2012). Traditionally using antidiabetic medicinal plants in Tamil Nadu. International Journal of Research in Pharmaceutical and Biosciences, 2, 1-8.

Kale, R. H., Halde, U. K., \& Biyani, K. R. (2012). Protective effect of aqueous extract of Uraria picta on acetaminophen induced nephrotoxicity in rats. International Journal of Research in Pharmaceutical and Biomedical Sciences, 3, 110-113.

Kasar, R. P., Laddha, K. S., Chaudhary, J., \& Shukla, A. (2007). Chyawanprashtruth or myth. Pharmacognosy Reviews, 1, 185-190. 
Khalili, M. A., Norhayati, A. H., Emynur, S. S., Mohamad, F. G., Azlina, M., Tajul, Z. M., \& Ahmad, Z. A. L. (2012). Screening of seven types Terengganu herbs for their potential antibacterial activity against selected food spencer microorganisms. Borneo Science, 2012, 11-27.

Khanna, A. K., Chander, R., \& Kapoor, N. K. (1991). Hypolipidaemic activity of abana in rats. Fitoterapia, 62, 271-276.

Kirtikar, K. R., \& Basu, B. D. (1993). An I.C.S., Indian Medicinal Plants. Bishen Singh Mahendra Pal Sigh, Dehradun.

Kojima, H., Sato, N., Hatano, A., \& Ogura, H. (1990). Sterol glucosides from Prunella vulgaris. Phytochemistry, 29, 2351-2355.

Lambo, J. O. (1979). The healing power of herbs with special reference to obstetrics and gynecology. Sofowora, A. (Ed). University of Ife Press, Ile-Ife. 23-30.

Makinde, S. C. O., Ojekale, A. B., Oshinaike, T. S., \& Awusinu, T. S. (2015). An ethnomedical and ethnobotanical survey of plants herbal therapy used for obesity, asthma, diabetes and fertility by the Badagry people of Lagos State, Nigeria. Journal of Medicinal Plants Studies, 3, 1-6.

Minu, V., Harsh, V., Ravikant, T., Paridhi, J., \& Noopur, S. (2012). Medicinal plants of Chhattisgarh with anti-snake venom property. International Journal of Current Pharmaceutical Research, 3, 1-10.

Mishra, R. K., Patel, S. P., Srivastava, A., Vashistha, R. K., Singh, A., \& Puskar, A. K. (2012). Ethnomedicinally important plants of Pachmarhi region, Madhya Pradesh, India. Nature and Science, 10, 22-26.

Mukherjee, P. K., \& Wahile, A. (2006). Integrated approaches towards drug development from Ayurveda and other Indian system of medicines. Journal of ethnopharmacology, 103(1), 25-35. https:// doi.org/10.1016/j.jep.2005.09.024

Mukundan, U., Sivaram, L., \& Kumar, A. (2002). Micropropagation of Tylophora asthmatica and Uraria picta. Plant Cell Biotechnology and Molecular Biology, 3, 73-76.

Newman, D. J., \& Cragg, G. M. (2012). Natural products as sources of new drugs over the 30 years from 1981 to 2010. Journal of Natural Products, 75(3), 311-335. https://doi.org/10.1021/np200906s

Nikam, T. D., Ghorpade, R. P., Nitnaware, K. M., Ahire, M. L., Lokhande, V. H., \& Chopra, A. (2013). Micropropagation and non-steroidal antiinflammatory and anti-arthritic agent boswellic acid production in callus cultures of Boswellia serrata Roxb. Physiology and molecular biology of plants : an international journal of functional plant biology, 19(1), 105-116. https://doi.org/10.1007/s12298-012-0137-3

Odubanjo, V. O., Oboh, G., \& Ibukun, E. O. (2013). Antioxidant and anticholinesterase activities of aqueous extract of Uraria picta (Jacq.) DC. African Journal of Pharmacy and Pharmacology, 7, 2768-2773.

Okusanya, O., Lakanmi, O., \& Oyesiku, O. (1991). Germination ecology of the woody herb Uraria picta, from southern Nigeria. Journal of Tropical Ecology, 7(1), 139-146. https://doi.org/10.1017/S0266467400005204

Osazuwa, E. O., \& Igboechi, A. C. (1988). Anti-microbial activity of a chemical isolate from leaves of Uraria picta. Phytotherapy Reasearch, 2, 204-206

Oyesiku, O. O., Okusanya, O. T., \& Olowokudejo, J. D. (2013). Morphological and anatomical investigations into the mechanism of leaf pair unrolling in Uraria picta (Jacq.) Desv. Ex DC. (Papilionaceae), a medicinal plant in Nigeria. African Journal of Traditional, Complementary, and Alternative Medicines 10(4), 144-150. https://doi.org/10.4314/ajtcam.v10i4.23

Parmar, V. R., \& Jasrai, Y. T. (2012). In vitro propagation of a Dasamula medicinal plant- Prithakparni. CIB Tech Journal of Biotechnology, 2, 1-5.

Parmar, V. R., \& Jasrai, Y. T. (2015). Effect of thidiazuron (TDZ) on in vitro propagation of valuable medicinal plant: Uraria picta (Jacq.) Desv. ex DC. Journal of Agricultural Research, 53, 513-521.

Parsons, I. C. (1991). Phytochemical studies on some species of the allied Rutaceae and Burseraceae. Ph.D. Thesis, University of Strathclyde, UK

Patel, B. D., Kamariya, Y. H., \& Patel, M. B. (2011). Free radical scavenging potential of ethanolic extract of Uraria picta Linn. Pharmacology online, 2, 134-145.

Patwardhan, B., Chopra, A., \& Vaidya, A. D. B. (2003). Herbal remedies and the bias against ayurveda. Current Science, 84, 1165-1166.
Prasad, G. C., Sankaran, P. S., \& Deshpande, P. J. (1965). Studies on fracture healing by using radioactive P32 and Ca45 under the influence of Uraria picta. Indian Journal of Medical Research, 53, 645-650.

Rahman, A. H. M. \& Parvin, M. I. A. (2014). Study of medicinal uses on Fabaceae family at Rajshahi, Bangladesh. Research in Plant Sciences, 2, 6-8.

Rahman, M. M., Gibbons, S., \& Gray, A. I. (2007). Isoflavanones from Uraria picta and their antimicrobial activity. Phytochemistry, 68(12), 1692-1697. https://doi.org/10.1016/j.phytochem.2007.04.015

Rahmatullah, M., Ferdausi, D., Mollik, A. H., Azam, N. K., Taufiq-UrRahman, M., \& Jahan, R. (2009). Ethnomedicinal survey of Bheramara area in Kushtia District, Bangladesh. American-Eurasian Journal of Sustainable Agriculture, 3, 534-541.

Rai, S. K., Sharma, M., Jain, M., Awasthi, A., Purshottam, D. K., Nair, N. K., \& Sharma, A. K. (2010). Rapid in vitro production of cloned plants of Uraria picta (Jacq.) DC-A rare medicinal herb in long-term culture. Applied Biochemistry and Biotechnology, 162(7), 1929-1937. https://doi.org/10.1007/s12010-010-8970-8

Sahu, S. C., Dhal, N. K., \& Mohanty, R. C. (2010). Potential medicinal plants used by the tribal of Deogarh district, Orissa, India. Studies on Ethnomedicine, 4, 53-61.

Saxena, H. O., Soni, A., Mohammad, N., \& Choubey, S. K. (2014). Phytochemical screening and elemental analysis in different plant parts of Uraria picta Desv.: A Dashmul species. Journal of Chemical and Pharmaceutical Research, 6, 756-760.

Sikarvar, R. L. S., Pathak, B., \& Jaiswal, A. (2008). Some unique ethnomedicinal perception of tribal communities of Chitrakoot, Madhya Pradesh. Indian Journal of Traditional Knowledge, 7, 613-617.

Singh, R. S., Ahmad, M., Wafai, Z. A., Seth, V., Moghe, V. V., \& Upadhyaya, P. (2011). Anti-inflammatory effects of Dashmula, an ayurvedic preparation, versus diclofenac in animal models. Journal of Chemical and Pharmaceutical Research, 3, 882-888.

Thomas, B., Arumugam, R. Veerasamy, A., \& Ramamoorthy, S. (2014) Ethnomedicinal plants used for the treatment of cuts and wounds by Kuruma tribes, Wayanadu districts of Kerala, India. Asian Pacific Journal of Tropical Biomedicine, 4, 488-491.

Tripathi, Y. C. (2000). Ethno medicinal treasure of tribal Rajasthan. Journal of Non-Timber Forest Products, 7(1-2), 77-84.

Turner, B. L., \& Harborne, J. B. (1967). Distribution of canavanine in the plant kingdom. Phytochemistry, 6, 863-866.

Ved, D. K., \& Goraya, G. S. (2008). Demand and supply of medicinal plants in India. In: Singh, B., Singh, M.P. (Ed.). Publishers and Distributors of Scientific Books, Dehradun.

Wagh, V. V., \& Jain, A. K. (2014). Ethnomedicinal uses of underground plant parts in Jhabua District of Madhya Pradesh, India. Advances in Biological Research, 8, 151-156.

Wagh, V. V., \& Jain, A. K. (2015). Inventory of ethnobotanicals and other systematic procedures for regional conservation of medicinal and sacred plants. Environ Systems and Decision, 35, 143-156.

Waghire, H. B., Shaikh, F. K., Jaiwal, B. V., \& Pokle, D. S. (2013). Polymorphism of albumin like proteins in three species of genus Uraria. International Journal of Research in Pharmaceutical and Biomedical Sciences, 4, 939-942.

Waghire, H. B., Survase, S. A., \& Pokle, D. S. (2011). A Preliminary Study on the Germination of Uraria picta (Jacq.) DC. Journal of Ecobiotechnology, 3, 28-30.

WHO, (2002). WHO Traditional medicinal strategy. World Health Organization, Geneva. Yadav, A.K., Yadav, D., Shanker, K., Verma, R.K., Saxena, A.K., \& Gupta, M.M. (2009). Flavone glycoside based validated RP-LC method for quality evaluation of Prishniparni (Uraria picta). Chromatographia, 69, 653-658.

Yusuf, M., Chowdhury, J. U., Wahab, M. A., \& Begum, J. (1994). Medicinal plants of Bangladesh. BCSIR Laboratories, Chittagong, Bangladesh.

Yusuf, M., Wahab, M. A., Yousuf, M. D., Chowdhury, J. U., \& Begum, J (2007). Some tribal medicinal plants of Chittagong hill tracts, Bangladesh. Bangladesh Journal of Plant Taxonomy, 14, 117-128. 